\title{
South Africa's freight rail reform: A demand-driven perspective
}

\begin{abstract}
Authors:
Jan H. Havenga

Zane P. Simpson

Anneke de Bod ${ }^{1}$

Affiliations:

${ }^{1}$ Department of Logistics,

Stellenbosch University,

South Africa

Correspondence to:

Jan Havenga

Email:

janh@sun.ac.za

Postal address:

Private Bag X1, Matieland

7602 , South Africa

Dates:

Received: 05 Aug. 2014

Accepted: 17 Aug. 2014

Published: 21 Nov. 2014

How to cite this article:

Havenga, J.H., Simpson, Z.P.

\& De Bod, A., 2014, 'South

Africa's freight rail reform: A

demand-driven perspective',

Journal of Transport and

Supply Chain Management

8(1), Art. \#153, 7 pages.

http://dx.doi.org/10.4102/

jtscm.v8i1.153
\end{abstract}

\section{Copyright:}

(C) 2014. The Authors.

Licensee: AOSIS

OpenJournals. This work

is licensed under the

Creative Commons

Attribution License.
During the 20th century, freight transport in South Africa was employed to attain politicoeconomic ideals, resulting in the overprotection of rail and overregulation of road transport. Increasing industry pressure, combined with the international deregulation trend, led to deregulation in 1988. Myopia resulted in a rail investment hiatus and exponential growth in high-value, long-distance road transport, causing excessive logistics and externality costs for the country. The aim of this study was to propose a freight rail reform agenda based on, (1) lessons from past freight transport policy efforts and (2) the results of freight transport market segmentation driven by models developed over the past two decades. For the study, freight flows were modelled by disaggregating the national input-output model into 372 origin-destination pairs and 71 commodity groups, followed by distance decay gravitymodelling. Logistics costs were calculated by relating commodity-level freight flows to the costs of fulfilling associated logistical functions. The standard management approach of founding strategy development on market-driven segmentation provides a neutral input to steer rail reform discussions in South Africa. Market segmentation points to a dualistic rail reform agenda, enabling both a profit-driven core and a development-driven branch line network. Freight flow insights are steering the policy reform debate towards long-term freight strategy development and optimal freight logistics network design.

\section{Introduction}

Efficient freight transport is an important driver of national competitiveness and is especially pertinent in South Africa, where transport costs contribute $61 \%$ of logistics costs (Havenga \& Simpson 2012), compared to the global average of 39\% (Rodrigue, Comtois \& Slack 2009). South Africa's industrial concentration in the middle of the country, which developed around mining deposits, is served by long, dense freight corridors to and from ports and agricultural communities. Road freighters have an almost $90 \%$ corridor tonne-kilometres (tonne-km) market share (Havenga \& Simpson 2012). Forty percent of road transport cost is attributable to fuel costs (Havenga \& Simpson 2012) and, with more than two-thirds of the country's crude oil being imported (US Energy Information Administration 2013), the country is placed under untenable exogenous risk. Dense long-distance corridors are ideal candidates for intermodal rail (Rodrigue, Slack \& Blank 2008), which is spearheading the global rail revival, with US domestic intermodal volume growth of 25\% in 2012 (Watson 2013) and a 29\% twenty-foot equivalent units (TEU) growth between 2005 and 2011 in the EU for international and domestic intermodal combined (International Union of Railways 2013). The American Trucking Association (2013) forecasts that intermodal rail will continue to be the fastest-growing freight mode in the next decade.

The failure of South Africa's freight railway to capture this market is attributable to a lack of policy direction regarding the role of the two modes (road and rail) in the surface freight transport industry (Development Bank of Southern Africa [DBSA] 2012), caused by the absence of sufficient market intelligence to inform policy (Havenga 2007). In this article, a direction for the rail reform debate in South Africa is envisaged, based, firstly, on learnings from the policy environment in the 20th century and, secondly, on market-driven freight flow segmentation.

\section{Literature review}

The role of the government is, primarily, to facilitate the development of a long-term logistics strategy that optimally equilibrates demand and supply (Dollery \& Wallis 1985) through 'anticipation' of the market character (Antonowicz 2011:277). The definition of a national network of road and rail infrastructure and their intermodal connections will flow from this, presupposing neutrality across modes by taking full account of all relevant social, environmental, economic and land-use factors. This ensures that the mix of transport modes reflects their intrinsic efficiency, rather than government policies and regulations that favour one mode over another. The strategy is subsequently enabled by a clearly defined freight policy, a single funding regime for the national network and, lastly, the establishment of appropriate regulatory 
and institutional mechanisms to facilitate implementation (Australian Government Productivity Commission 2005). These steps echo the canonical management cycle of market intelligence, strategy development, business design, funding and implementation.

The absence of the first two steps in South Africa's freight policy planning process led to a fixation on vertical separation for the national railway during the early part of the 20th century. This fixation mainly resulted from theimplementation of vertical separation and open access in the UK and EU. Vertical separation proposals, however, met with significant resistance in South Africa, informed by inconclusive results elsewhere, as discussed in the next section.

\section{Global experience with vertical separation}

The specific benefits that were expected to follow from the vertical separation of railway infrastructure and operations, and/or open access, were to encourage competition (as in Australia), facilitate international services (as in Europe) and to put different modes on an equal footing (as in Scandinavia) (Gomez-Ibanez \& De Rus 2006). However, according to Drew and Nash (2011), on existing evidence there is no reason to conclude that vertical separation improves competition, growth in rail traffic or rail's modal share. Beria et al. (2010) confirm that the empirical evidence regarding vertical unbundling is inconclusive. In contrast, in a comparative analysis of vertically integrated and separated railways in the EU, Drew and Nash (2011) show that, for the period 1998-2008, tonne-km traffic on vertically separated railways hardly grew, whilst traffic on vertically integrated railways grew by about $40 \%$.

Pittman (2005:182) remarks that 'one of the specific lessons of the experience to date is that the freight railways sector may not be a very promising sector for vertical separation'. This is the result of high proportions of fixed cost, upstream economies of scale and the locus of vertical separation. Research suggests that $25.0 \%$ of delivered costs of railroads are infrastructure costs, versus $5.0 \%$ for electricity and $2.5 \%$ for gas (Thompson 2003). In addition, small power plants, for instance, can be just as competitive as bigger plants, whereas density is the holy grail of railroads. As Pittman (2005:185) states, 'the effectiveness of the operations depends on the exact point where vertical integration or vertical separation takes place' - that is, at the interface point between fixed and rolling infrastructure (Sanchez 2001). As such, only the very busiest railway networks, which can exploit the density potential of volume growth, are likely to generate sufficiently high financial returns to attract substantial risk capital in long-term railway infrastructure (Amos 2006). The Association of American Railroads (2013) also highlights the impact of density on efficiency, revenue and, ultimately, the ability to reinvest.

Paradoxically, the problems associated with information asymmetries during vertical separation and the successful processes to address them lead to deep relationships between interested parties. The mooted advantages of vertical separation are then negated by the fact that an industry with a few highly specialised players and highly integrated operations will require these relationships to be successful (Sanchez 2001). This inevitably leads to 'cooperation, quasi-reintegration, all that contribute to limit the role of market forces contrary to what was apparently planned in the first years of the railway reform' (Bouf, Crozet \& Lévêque 2005:11). Vertical separation also has a negative impact on decision making and gives rise to the potential for underinvestment (Amos, 2006; Australian Government Productivity Commission 2005; Drew \& Nash 2011). A recent report on UK rail privatisation states that privatisation has failed to deliver benefits, with trainoperating companies entirely reliant upon public subsidies to run services and that $90 \%$ of new investments have been made by the government-owned infrastructure company (Trade Union Congress 2013). In many circles, this failure is blamed on the adverse impact of vertical separation on railway functioning, because 'in a railroad, the operation is so tightly connected with infrastructure' (Smith, S. 2012:1). By 2014, estimates are that more than $95 \%$ of rail traffic is still handled by vertically integrated railways (Organisation for Economic Cooperation and Development 2014).

\section{Research method and design}

The evolution of South Africa's surface freight transport industry is based on a critical evaluation of available literature. Market segmentation is based on a freight flow and a logistics cost model. Historically, the lack of disaggregated and complete volume data on the freight transport sector in South Africa, and a complete absence of road transport cost data, significantly hampered analysis and subsequent policy recommendations, as highlighted by Naude (1999). This dearth has been corrected in this century by extensive gravity-based freight flow analysis between 372 defined origin and destination pairs and for 71 commodity groupings (including a 30-year forecast), based on a disaggregated input-output model of the economy.

Gravity-based approaches are based on the premise that freight flows between origins and destinations are determined by supply and demand and a measure of transport resistance (Krygsman 2006). For the purposes of this research, the transport resistance measure used was a distance decay function. The costs of performing transport, storage and port handling functions with respect to each freight flow are then modelled. The cost of holding inventory is added by calculating the average turn of each commodity in the economy, researching warehousing cost (storing and handling) and applying the prime rate to the average inventory delay. The actual disaggregated rail freight flows and costs are obtained from South Africa's single freight rail operator; the balance of the flow and cost data therefore defines the road transport mode. The models are prepared in conjunction with industry experts and independently verified by a team of economists (refer to Havenga 2007, 2010 and 2012 for methodology detail). It is one of the most comprehensive freight segmentation models 
in the world, enabling aggregation to national-level intelligence to inform policies, large-scale infrastructure investments and industrial positioning. At the same time, it also allows disaggregation to the local level to enable practical application.

\section{Results}

\section{Evolution of South Africa's surface freight transport industry}

Railway companies from the four separate British colonies in South Africa were unified in 1910 and institutionalised as a government organ with the creation of the Union of South Africa. Rail network development was characterised by expansive development in the first two decades of the 20th century to support inland agricultural and industrial development through cheap transport services - without due regard for the future demand for this network, that is, the fundamental rail economic principle of density. This resulted in explicit tariff cross-subsidisation from highervalue products to sustain the low-density portions of the network. The advent of road freight transport in the 1920s was specifically attractive to this higher-value traffic because of its flexibility and more transparent pricing structure, which placed rail's business model at risk. Instead of reevaluating this business model, the risk of road transport was eliminated through the regulation of long-distance road freight transport (Dollery \& Wallis 1985). Market needs dictated the development of a long-haul road freight industry in the absence of satisfactory rail solutions.

Recommendations from the National Transport Policy Study led to a partial official relaxation of this protection in 1977 and complete economic deregulation by 1988 (Martin 2004). This was replaced with technical and safety regulation, encompassed in the Road Transport Quality System. Implementation was, however, a dismal failure, allowing road operators to overload, practice unsafe driving operations and poorly maintain equipment (Cronin 2011; Webster 2001). In addition, road-user charges were not adjusted to fully recover road infrastructure costs. When greater importance is given to transport externalities in modal choice, this favours the use of intermodal transport (Meers, Macharis \& Van Lier 2013).

Investment in railway infrastructure and services (such as intermodal) that could compete with road was a nonstarter because of a lack of capital brought about by political turmoil in the late 1980s during the last years of the apartheid government, debilitating sanctions and war spending in Namibia and Angola. Rather than renewal, the government curtailed all rail investment. These events were exacerbated by an increase in the maximum permissible vehicle mass from 22 tonnes in 1970 to 56 tonnes in 1989 (Cronin 2011; Parliamentary Monitoring Group 2000) - compare this to the maximum weight of trucks at 40 tonnes in the majority of EU countries (International Transport Forum 2011). This was compounded by considerable ageing of the rail fleet (making it less suitable for the changing market needs). The end result of all these factors was an unprecedented growth in road freight and a failure of rail to exploit the density advantage of the freight corridors that were beginning to form. The growth in road freight is evidenced by the exponential rise in South Africa's truck fleet from 20000 vehicles in 1950 to 340000 in 2012, a compound annual growth rate of 5\% (Electronic National Traffic Information System 2012).

In 1990, the rail system, together with ports and pipelines (and other ancillary businesses) were eventually amalgamated in one state-owned enterprise, Transnet. During the early 1990s, the new democratic government did, however, put in place a framework to improve the country's economic competitiveness through the development of existing and new harbours, a high-class road system on the key longdistance routes, vastly improved airports and efficient pipeline infrastructure for the conveyance of petroleum products. Unfortunately, an ageing and inefficient rail infrastructure system was not addressed (Mitchell 2004).

The deregulation of the freight transport industry was followed by a freight transport policy implementation vacuum that has lasted for almost two decades. Moving South Africa (MSA) (National Department of Transport [DoT] 1998) was a data-driven programme to develop a long-term strategy embodying the trade-offs necessary to realise the vision of the 1996 White Paper on National Transport Policy (DoT 1996) for an integrated land freight transport system that would meet the country's economic and social ideals. Acute skills shortages in government, together with discomfort with the potential employment and social fallout of implementation, unfortunately resulted in non-implementation. In addition, by 2005, the growth of freight traffic had surpassed most of the 20-year growth forecasts made by MSA - at least 14 years before they were expected (DoT 2005). The significant pressure placed on the freight system to service this (unforeseen) growth in demand increased pressure on government to overhaul the industry, resulting in the release of the National Freight Logistics Strategy (NFLS) in 2005 (DoT 2005). The proposed solutions were integrated planning, vertical separation and more direct government involvement, especially by taking over control of rail infrastructure. The NFLS was met with resistance, mainly because of contradictory data regarding the benefits of vertical separation in the international arena discussed previously and the suggested single-network characteristic of South Africa's railway system (Havenga 2012).

This was followed by a Green Paper on rail policy in 2011 (Mahlalela 2011) that was opposed by many experts in South Africa prior to publication and subsequently withdrawn. As with NFLS, its treatment of open access and vertical separation still met with significant opposition. The updated Green Paper from the Department of Transport, released in 2013 to limited stakeholders for comment, indicates a turnaround 'to change the thrust of rail policy away from one that is focused on institutional reform and clarity [towards one] that encourages development and investment' (Smith, N. 2012:1). Reference to the Department's work on the Green Paper includes 
comments from the Minister of Transport in parliament whilst responding to a question from a house member (National Assembly 2013) and in a speech on the occasion marking the launch of the October 2013 'Transport Month' (Peters 2013).

Investment-led reform is a shift in the right direction, but the canonical approach of business design based on a careful analysis of market needs, followed by investment and implementation through the standard management and planning cycle, is still lacking. Regulation, restructuring and liberalisation is part of the last step and by moving up investment on the agenda, the latest version of the Green Paper that is currently discussed (National Assembly 2013; Peters 2013) has made significant progress. Rail economic regulation was still urged recently (Mahlalela 2011), with the overarching objective of more efficient and effective rail services (Khuthele Projects 2007). Increased efficiency and effectiveness should, however, be considered for South Africa's freight system and not railways in isolation (after all, only $10 \%$ of the nation's freight bill is spent on rail) and this principle is reflected in the Transport Ministry's most recent policy statement (Martins 2013). It is implied that modal shift will decrease total freight costs, but one of the direct drivers is, in fact, the cross-subsidisation of road freight by other road users. Given the above analysis, a role for a transport economic regulator should be specifically related to facilitating integrated planning and investment and achieving competitive neutrality across all transport modes through the internalisation of all costs.

The challenges facing the implementation of transport policy in South Africa is discussed in detail in Havenga (2011). These relate to the lack of a single point of accountability for the country's logistics system, both exacerbated by and exacerbating (as a result of fragmentation) the country's skills shortage. In addition, there are disjointed policy developments within and between the two ministries - the Department of Transport and the Department of Public Enterprises (responsible for Transnet) - resulting in fragmented infrastructure investments and limited publicprivate collaboration.

Ministerial churn is adding to the skills and implementation challenge - in the past 20 years there have been five ministers of transport in South Africa, of which the last one served only 1 year (he was replaced in July 2013) (Freight \& Trading Weekly 2013) and his predecessor served only 3 years. As experienced in the UK, this 'encourages an unhelpfully short-term approach to policy' (Cleary \& Reeves 2009:2), a dire consequence in an industry where investments have long delivery lead times and extremely long life spans.

Ministries of transport frequently do not have adequate resources to facilitate reform (Beria et al. 2010). The Australian experience confirms that an overly compartmentalised approach to freight transport reform leaves a legacy of distortions that create modal biases in the movement of freight. The most commonly cited example is overuse of, and excessive investment in, road transport at the expense of rail. Over the longer term, it puts at risk the economic, environmental and social benefits that may only be realised by taking a more holistic approach (Australian Government Productivity Commission 2005). The research results presented in the next section provide a fresh perspective on rail reform through such a holistic analysis of freight transport demand needs.

\section{Market segmentation}

In 2012, South Africa's surface freight transport industry moved 1.8 billion tonnes of freight over an average transport distance of $246 \mathrm{~km}$, delivering 432 billion tonne- $\mathrm{km}$ to the economy. The total freight bill to provide this work was R247 billion, excluding externalities of approximately R40 billion. Rail's share of this effort was $30 \%$ of tonne- $\mathrm{km}, 12 \%$ of tonnes shipped, $10 \%$ of costs and a negligible share of externalities. Rail, however, delivered only $13 \%$ of the long-haul tonne-km (excluding bulk mining) (Havenga \& Simpson 2012). This poses a significant cost risk to the country and its industry, as the long-haul modal imbalance results in two-thirds of total surface freight transport costs (road and rail) being spent on corridors, with $95 \%$ of the corridor transport costs attributable to road transport (Havenga 2012). The composition of surface freight transport costs based on the macroeconomic value chain is depicted in Figure 1. Three-quarters of transport costs are associated with domestic flows, with rail's downstream tonne-km market share reducing to negligible figures. Rail's low market share is especially disconcerting when defining long-distance flows (flows in excess of $400 \mathrm{~km}$ ), because each of these long-distance segments can be served by rail, as described in Table 1.

Mining is rail's traditional strength. Compare, however, the rail market shares in the other long-distance segments to Allen and Gallamore's (2011:37) statement that US railways were on 'the brink of ruin', with intercity (long-distance) freight tonne-mile market share dropping to $35 \%$ in the mid-1970s.

TABLE 1: Long-distance freight transport demand per economic sector in 2011.

\begin{tabular}{lccll}
\hline Transport demand & Tonne-km (billions) & Rail share (\%) & Description \\
\hline $\begin{array}{l}\text { Agricultural commodities } \\
\text { Mining commodities }\end{array}$ & 20 & 6 & $\begin{array}{l}\text { Low-density flows of uniform commodities between many } \\
\text { rural collection centres and processing plants and ports. }\end{array}$ & $\begin{array}{l}\text { Shorter collection trains and some block } \\
\text { trains. }\end{array}$ \\
$\begin{array}{l}\text { Intermediate commodities } \\
\text { Dense flows of uniform commodities between mines and }\end{array}$ & $\begin{array}{l}\text { Bulk block trains between sidings. } \\
\text { beneficiation centres and ports. }\end{array}$ \\
$\begin{array}{l}\text { Finished products } \\
\text { Medium-density flows of non-uniform commodities between Medium-density trains with a wide variety } \\
\text { plants (i.e. siding-to-siding flows) }\end{array}$ & 85 & 14 & $\begin{array}{l}\text { Very high-density, mostly bi-directional flows of high-value } \\
\text { palletisable commodities between a few large industrial } \\
\text { metropoles. }\end{array}$ \\
\hline
\end{tabular}

Source: Havenga, J.H., 2013, 'The relevance of commodity-flow modelling in freight transport demand forecasts', Paper presented at the 25th Nordic Logistics Research Network (NOFOMA) conference, Gothenburg, Sweden, 04-05 June 
The key rail economics principles are density (i.e. more tonne$\mathrm{km}$ per route-kilometre), distance and freight uniformity (achieved through containerisation for finished products) (Havenga 2012). The definition of rail freight's role should thus strive for a core network with the greatest possible density. The missed opportunity of rail's 3\% long-distance finished-goods market share is highlighted when the freight segments are depicted according to these principles, as in Figure 2 (the depiction excludes rail's world-class bulk export lines where a road solution is not possible). The potential of rail to serve these long-distance segments is confirmed in the 2011 European Commission Transport White Paper, where a modal shift of $50 \%$ of the road freight over $300 \mathrm{~km}$ to rail and waterborne transport by 2050 is targeted (Meers et al. 2013), enabled by intermodal transport as the key technology driving both revival in rail and increased efficiency in the transport sector as a whole (Allen \& Gallamore 2011; Antonowicz 2011). This presupposes the creation of dedicated transport corridors aimed at improving the reliability, efficiency and competitiveness of all modes (Antonowicz 2011; Australian Government Productivity Commission 2005).

South Africa's freight task is expected to treble over the next 30 years, with further concentration on the long-distance corridors, as depicted in Figure 3. The significant growth lends even more weight to implement the clear priorities for rail reform that emerge from Figure 2; that is, (1) to develop an intermodal service for long-distance finished products and develop strategies to further rail freight services for long-distance intermediate traffic, (2) to maintain and develop rail's core competency around the transport of mining commodities and (3) to revive the low-density branch line network through government involvement in order to facilitate rural employment and equitable access to the core transport network. This will result in a core network that can operate as a profitable business with returns that can satisfy both shareholders' and infrastructure capacity requirements, whilst reducing the country's freight transport bill and alleviating the risk of fuel imports and externalities (especially congestion and emissions). Instead of a myopic focus on rail reform for its own sake, the development of South Africa's transport industry policy and subsequent regulation should facilitate a shift to these priorities.

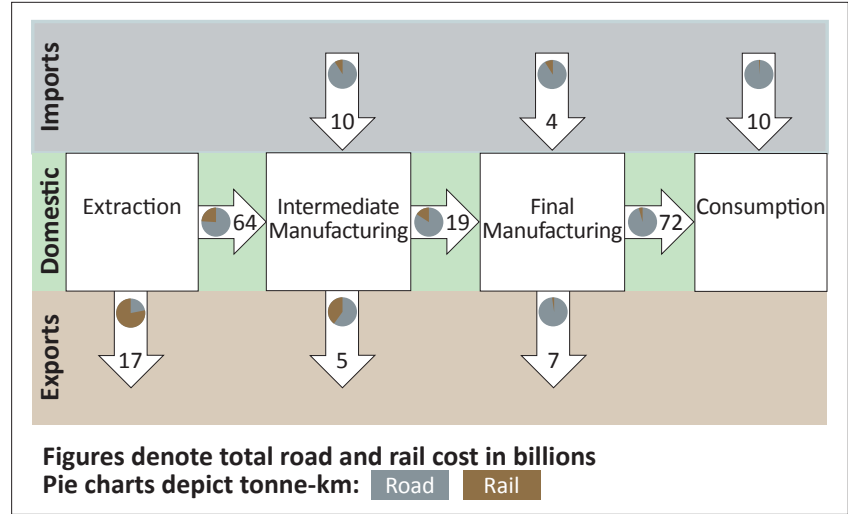

Source: Havenga, J.H., 2013, 'The relevance of commodity-flow modelling in freight transport demand forecasts', Paper presented at the 25th Nordic Logistics Research Network (NOFOMA) conference, Gothenburg, Sweden, 04-05 June

FIGURE 1: The overarching South African value chain and associated logistics costs in 2011.

\section{Conclusion}

Despite South Africa's freight transport policy implementation challenges identified in this article, there have been major tangible advances that should enable the fast-tracking of an integrated freight transport vision. Onethird of public-sector infrastructure expenditure over the period 2010-2011 to 2014-2015 is allocated to transport and logistics infrastructure spending (DBSA 2012). Over the past two decades, Transnet has sold off its non-core assets, focusing solely on freight transport, introduced separated reporting and commercialised management and has made unprecedented infrastructure investments, culminating in a record R23 billion capital investment in 2013 (Transnet 2013). The management of national roads is under a separate entity, the South African National Roads Agency Limited, and major road investments are on-going (DBSA 2012). Global logistics players are on board with the imperative for the development of intermodal solutions (Imperial Logistics 2013).

However, one of the key requirements for an efficient national freight transport system is better national coordination based on market-driven approaches (Australian Government Productivity Commission 2005). To avoid the ad hoc policy responses of the previous century,

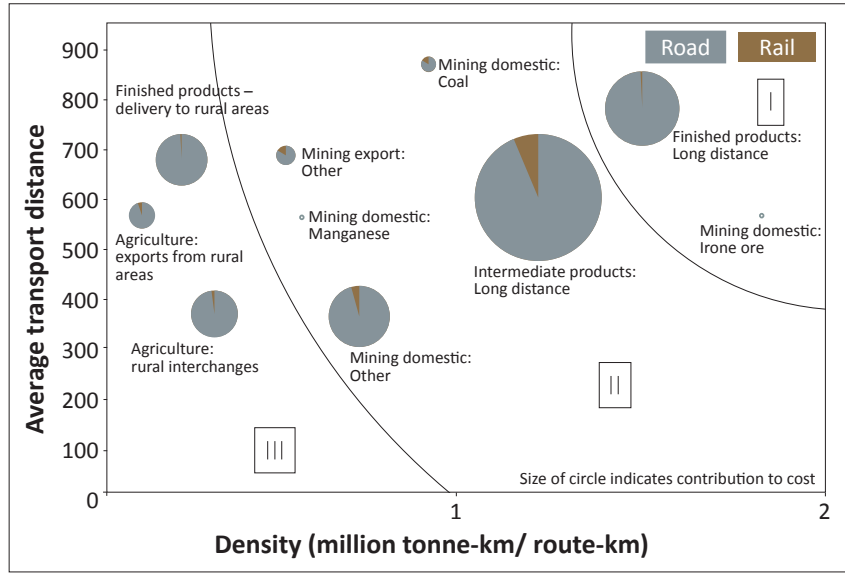

Source: Havenga, J.H., 2012, 'Rail renaissance based on strategic market segmentation principles', Southern African Business Review 16(1), 1-21

FIGURE 2: Long-distance freight market spaces based on distance, density and cost in 2008 (excluding ring-fenced rail exports of iron ore, coal and manganese).

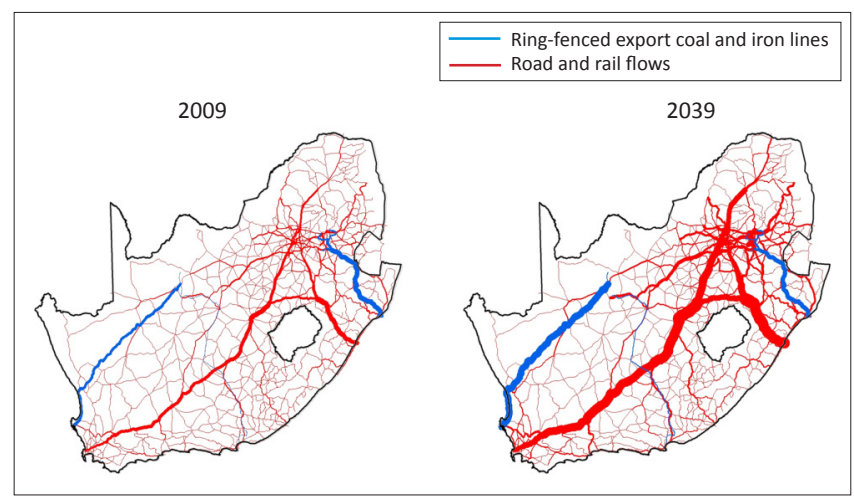

Source: Havenga, J.H., 2013, 'The relevance of commodity-flow modelling in freight transport demand forecasts', Paper presented at the 25th Nordic Logistics Research Network (NOFOMA) conference, Gothenburg, Sweden, 04-05 June

FIGURE 3: Growth of surface freight flows in South Africa - 2009 versus 2039 (tonnes). 
which led to sub-optimisation, increasing complexity and decreasing end-user quality, the pressing reform issue for South Africa, therefore, is agreement on the design of an optimal freight logistics network based on a market-driven long-term strategy that holistically addresses the country's surface freight transport requirements. The market-driven freight flow segmentation presented in this article provides impetus for such a long-term strategy, pointing to the need for a profit-driven core rail network, as well as a development-driven branch line network.

\section{Acknowledgements Competing interests}

The authors declare that they have no financial or personal relationships that may have inappropriately influenced them in writing this article.

\section{Authors' contributions}

J.H.H. (Stellenbosch University) wrote up the manuscript, Z.P.S. (Stellenbosch University) was the modeller and A.d.B (Stellenbosch University) the project manager.

\section{References}

Allen, R. \& Gallamore, R.E., 2011, 'Freight on the move: How deregulation and technology transformed US railways', International Railway Journal, 50th Anniversary Special - March, 37-41.

American Trucking Association, 2013, US freight transportation forecast to 2024 - Just released!, viewed 21 July 2013, from http://www.truckline.com/article. aspx?uid=41434598-4c60-444d-bc83-38f06ded539d

Amos, P., 2006, 'Railway reform: Vertical integration and separation', EuroMed Transport Project: Railway Seminar and Study Tour, The World Bank, Paris, 11-20 September.

Antonowicz, M., 2011, 'Regulation and logistics in rail freight transport', The Archives of Transport XXIII(3), 275-284.

Association of American Railroads, 2013, Bottleneck policy: Don't fix what isn't broken, viewed 23 July 2013, from https://www.aar.org/keyissues/Documents/ Background-Papers/Bottleneck\%20Policy.pdf

Australian Government Productivity Commission, 2005, Review of nationa competition policy reforms, Report 33, Canberra, viewed 23 July 2013, from http://www.pc.gov.au/_data/assets/pdf_file/0016/46033/ncp.pdf

Beria, P., Quinet, E., De Rus, G. \& Schulz, C., 2010, 'A comparison of rail liberalisation levels across four European countries', Politecnico di Milano. MPRA Paper 29142, viewed 23 July 2013, from http://mpra.ub.uni-muenchen.de/29142/

Bouf D., Crozet, Y. \& Lévêque, J., 2005, 'Vertical separation, disputes resolution and competition in railway industry', Paper presented at the 9th Conference on Competition and Ownership in Land Transport, Lisbonne, France, 05-09 September.

Cleary, H. \& Reeves, C., 2009, The 'culture of churn' for UK Ministers and the price we all pay, viewed 22 July 2013, from http://www.demos.co.uk/files/Ministerial_ Churn.pdf

Cronin, J., 2011, 'The future of rail', Opening address at the Railways and Harbours Conference by Transport Deputy Minister Jeremy Cronin, 06 April, viewed 06 October 2014, from http://www.transport.gov.za/Portals/0/Media\%20 Satements/The\%20Future\%20of\%20Rail.doc

Development Bank of Southern Africa, 2012, The state of South Africa's economic infrastructure: Opportunities and challenges, viewed 23 July 2013, from http://www.gov.za/documents/download.php?f=174619

Dollery, B.E. \& Wallis, J.L., 1985, 'Conflict resolution and the deregulation of the South African transport sector', Development Southern Africa 2(4), 522-536. http://dx.doi.org/10.1080/03768358508439188

Drew, J. \& Nash, C.A., 2011, 'Vertical separation of railway infrastructure - Does it always make sense?', Working Paper 594, Institute for Transport Studies, University of Leeds, Leeds.

Electronic National Traffic Information System, 2012, Vehicle population statistic for 2011, viewed 06 October 2014, from http://www.enatis.com/index.php/ statistics/13-live-vehicle-population
Freight \& Trading Weekly, 2013, Transport minister changes - Again, viewed 14 July 2013, from http://www.ftwonline.co.za/News.aspx?NewsNo=19877

Gomez-Ibanez, J.A. \& De Rus, G., 2006, Competition in the railway industry: An international comparative analysis, Edward Elgar, Cheltenham. http://dx.doi. org/10.4337/9781847202949

Havenga, J.H., 2007, 'The development and application of a freight transport flow model for South Africa', PhD dissertation, Department of Logistics, Stellenbosch University.

Havenga, J.H., 2010, 'Logistics costs in South Africa: The case for macroeconomic measurement', South African Journal of Economics 78(4), 460-478. http://dx.doi org/10.1111/j.1813-6982.2010.01252.x

Havenga, J.H., 2011, 'Trade facilitation through logistics performance: The enabling role of national government', Journal of Transport and Supply Chain Management, November, $123-148$

Havenga, J.H., 2012, 'Rail renaissance based on strategic market segmentation principles', Southern African Business Review 16(1), 1-21.

Havenga, J.H., 2013, 'The relevance of commodity-flow modelling in freight transport demand forecasts', Paper presented at the 25th Nordic Logistics Research Network (NOFOMA) conference, Gothenburg, Sweden, 04-05 June.

Havenga, J.H. \& Simpson, Z., 2012, 'National logistics costs and global trends', in 9th Annual State of Logistics Survey for South Africa: Connecting neighbours - Engaging the world, pp. 2-19, CSIR, Pretoria, viewed 21 July 2013, from http://www.csir.co.za/sol/docs/final_9th\%20SoL\%20for\%20web.pdf

Imperial Logistics, 2013, Intermodal combines road and rail for big benefits, viewed n.d., from http://www.imperiallogistics.co.za/imperial-news/350/intermodalcombines-road-and-rail-big-benefit

International Transport Forum, 2011, Permissible maximum weights of trucks in Europe, viewed 14 July 2013, from http://www.internationaltransportforum.org/ IntOrg/road/pdf/weights.pdf

International Union of Railways, 2013, The UIC and its Combined Transport Group present '2012 Report on Combined Transport in Europe', Press Release 1-2013, viewed 21 July 2013, from http://www.uic.org/com/IMG/pdf/combined_ transport_en.pdf

Khuthele Projects, 2007, Comprehensive regulatory framework for setting up the rail economic regulator, Khuthele Projects, Pretoria.

Krygsman, S., 2006, Project notes for Transnet's commodity flow project, Department of Logistics, Stellenbosch University, Stellenbosch.

Mahlalela, G., 2011, Statement by George Mahlalela, Director-General of the Department of Transport, on plans to split Transnet to boost the ailing rail sector, 25 August, viewed 21 July 2013, from http://www.polity.org.za/article/ sa-statement-by-george-mahlalela-director-general-of-the-department-oftransport-on-plans-to-split-transnet-to-boost-the-ailing-rail-sector-25082transport-on-pli-2011-08-25

Martin, P., 2004, Railways in South Africa: Historic highlights, strategic evolution and transformation 1845-2002, Spoornet, Johannesburg.

Martins, D.B., 2013, Budget vote policy statement delivered by the Minister of Transport at the National Council of Provinces, 13 June, viewed 23 July 2013, from http://www.transport.gov.za/LinkClick.aspx?fileticket=wRhzIKEwsXA\%3D\&tabid= $644 \&$ mid $=1568$

Meers, D., Macharis, C. \& Van Lier, T., 2013, 'Modal choice in freight transport: A combined MCDA-GIS approach', 13th World Conference on Transport Research, 15-18 July, Rio de Janeiro, Brazil.

Mitchell, M., 2004, 'The history of transport infrastructure in South Africa during the past fifty years', Unpublished report prepared for the Development Bank of Southern Africa, Midrand.

National Assembly, 2013, Written reply to question no. 708 submitted on 29 April 2013 by the Minister of Transport, viewed 06 October 2014, from http://www. transport.gov.za/Portals/0/Parliamentary\%20docs/qno.\%20708.pdf

National Department of Transport, 1996, White Paper on national transport policy, DoT, Pretoria.

National Department of Transport, 1998, Moving South Africa: A transport strategy for 2020, DoT, Pretoria.

National Department of Transport, 2005, National freight logistics strategy, DoT, Pretoria.

Naude, W., 1999, 'Trade in transport services: South Africa and the General Agreement on Trade in Services', Draft report submitted to the Trade and Industrial Policy Secretariat, August.

Organisation for Economic Cooperation and Development, 2014, Peer review of railway freight development in Mexico, International Transport Forum report, viewed 13 June 2013, from http://www.internationaltransportforum.org/jtrc/ viewed 13 June 2013, from http://
peer-review/mexico-freight-rail.pdf

Parliamentary Monitoring Group, 2000, Spoornet programme \& structure: Briefing, viewed 10 July 2013, from http://www.pmg.org.za/minutes/20000403-spoornetprogramme-structure-briefing

Peters, D., 2013, Keynote address by the Minister of Transport, Ms Dipuo Peters MP, on the occasion marking the launch of the 2013 October Transport Month, 01 October 2013, Pretoria, viewed 06 October 2014, from http://www.transport. gov.za/Portals/0/Speeches/2013/Keynote $\% 20$ Address $\% 20$ by $\% 20$ the $\% 20$ Minister\%20of\%20Transport.pdf

Pittman, R., 2005, 'Structural separation to create competition? The case of freight railways', Review of Network Economics 4(3), 181-196. http://dx.doi. org/10.2202/1446-9022.1072

Rodrigue, J-P., Comtois, C. \& Slack, B., 2009, The geography of transport systems, 2nd edn., Routledge, New York. 
Rodrigue, J-P., Slack, B. \& Blank, S., 2008, Transport corridors in North America, viewed 12 July 2013, from http://people.hofstra.edu/geotrans/eng/ch2en/appl2en/ ch2a1en.html

Sanchez, P.C., 2001, 'Vertical relationships for the European railway industry', Transport Policy 8(2), 77-83. http://dx.doi.org/10.1016/S0967-070X(00)00039-1

Smith, N., 2012, 'Second thoughts over split of Transnet Freight Rail', Business Day, 17 September, viewed 23 July 2013, from http://www.bdlive.co.za/business/ transport/2012/09/17/second-thoughts-over-split-of-transnet-freight-rail

Smith, S., 2012, Why Britain's railway privatization failed, viewed 22 July 2013, from http://www.theatlanticcities.com/commute/2012/09/why-britains-railwayprivatization-failed/3378/

Thompson, L., 2003, 'The regulatory challenge in Russian railways', Presentation at OECD Seminar on Railways Reform, Moscow, 22 May.
Trade Union Congress, 2013, Rail privatisation has failed to deliver on its promises, says report, viewed 22 July 2013, from http://www.tuc.org.uk/industrial/tucsays report,

Transnet, 2013, Business with us - About Transnet, viewed 23 July 2013, from http://www.transnet.net/BusinessWithUs/MDS/External\%20Magazine\%20 $-\% 20$ Final.pdf

US Energy Information Administration, 2013, South Africa: Overview, viewed 22 July 2013, from http://www.eia.gov/countries/cab.cfm?fips=SF

Watson, R., 2013, Intermodal growth surges on truckload freight conversion, 09 January, viewed 17 July 2013, from http://www.wmc.org/issues/intermodalgrowth-surges-on-truckload-freight-conversion/

Webster, J., 2001, 'RTQS - A dead duck', Fleetwatch, October, viewed 22 July 2013, from http://www.fleetwatch.co.za/previous/Legislation/october01/41-RTQS.htm 